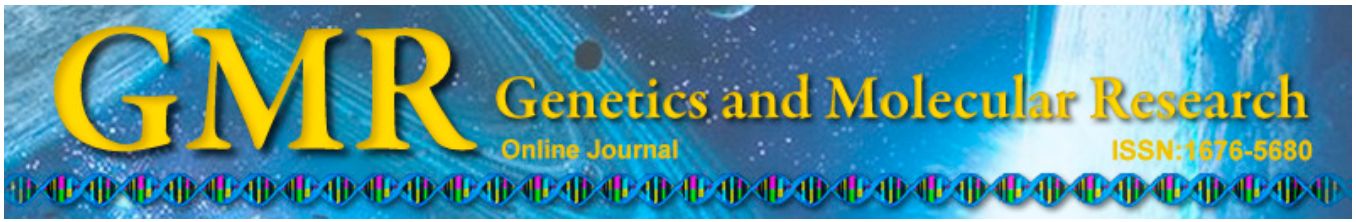

\title{
Association between methionine synthase reductase $A 66 G$ polymorphism and primary infertility in Chinese males
}

\author{
X.Y. Li ${ }^{1,2,3}$, J.Z. Ye ${ }^{1,2,3}$, X.P. Ding ${ }^{1,2,3}$, X.H. Zhang ${ }^{1,2,3}$, T.J. Ma ${ }^{1,2,3}$, \\ R. Zhong ${ }^{1,2,3}$ and H.Y. Ren ${ }^{1,2,3}$ \\ ${ }^{1}$ Institute of Medical Genetics, College of Life Science, Sichuan University, \\ Chengdu, China \\ ${ }^{2}$ Bio-Resource Research and Utilization Joint Key Laboratory of Sichuan and \\ Chongqing, Sichuan and Chongqing, China \\ ${ }^{3}$ Key Laboratory of Bio-Resources and Eco-Environment, \\ Ministry of Education, Chengdu, China \\ Corresponding author: X.P. Ding \\ E-mail: brainding@scu.edu.cn
}

Genet. Mol. Res. 14 (2): 3491-3500 (2015)

Received May 9, 2014

Accepted October 17, 2014

Published April 15, 2015

DOI http://dx.doi.org/10.4238/2015.April.15.13

\begin{abstract}
We examined the association between the methionine synthase reductase (MTRR A66G), methylenetetrahydrofolate reductase (MTHFR C677T and A1298C), and methionine synthase (MS A2756G) genotypes and non-obstructive male infertility in a Chinese population. This case-control study included 162 infertile Chinese patients with azoospermia $(\mathrm{N}=100)$ or oligoasthenozoospermia $(\mathrm{N}$ =62) and 120 fertile men as controls. The polymorphisms MTRR A66G, MTHFR C677T, A1298C, and MS A2756G were identified by direct DNA sequencing and the results were statistically analyzed. We found no association between the incidence of any of these variants in azoospermia patients and control populations. The frequency of the MTRR66 polymorphic genotypes (AG, AG+GG) was significantly higher in the oligoasthenozoospermia group compared to the controls
\end{abstract}


$(\mathrm{P}=0.013,0.012)$. Our findings revealed an association between the single-nucleotide polymorphism A66G in the MTRR gene and male infertility, particularly in oligoasthenozoospermia males, suggesting that this polymorphism is a genetic risk factor for male infertility in Chinese men.

Key words: Male infertility; Methionine synthase reductase; Methylenetetrahydrofolate reductase; Methionine synthase; Single-nucleotide polymorphism

\section{INTRODUCTION}

Infertility is defined as the failure of a couple to conceive after 12 months of unprotected regular sexual intercourse, which affects $15-30 \%$ of couples attempting to conceive (Kara and Simoni, 2010). Male factor infertility is partially or fully responsible for approximately $50 \%$ of infertility cases (Ammar et al., 2012). Infertility can be classified as primary or secondary, depending on whether a pregnancy was once induced or was not induced (Simoni and Wieacker, 2010). There are endocrinological (e.g., trauma to the pituitary), infectious (e.g., mumps orchitis), toxicological (e.g., lead exposure, exogenous androgen, chemotherapeutic drugs), and radiological (e.g., therapeutic radiation or occupational exposure) etiologies for male infertility, which is related to several risk factors such as chromosomal abnormalities (Kara and Simoni, 2010), Y chromosome micro/macrodeletions (Lee et al., 2011), cystic fibrosis transmembrane conductance regulator mutations (Augarten et al., 1994), and other genetic factors (Lee et al., 2003).

Folate is essential for DNA synthesis and methylation reactions (Fang and Xiao, 2003). DNA methylation plays an important role in spermatogenesis, and folate deficiency reduces hyperhomocysteinemia, which is considered to be a risk factor for various diseases, including infertility. Methionine synthase reductase (MTRR), methylenetetrahydrofolate reductase (MTHFR), and methionine synthase (MS) play essential and interrelated roles in folate metabolism (Figure 1). MTHFR catalyzes the conversion of methylenetetrahydrofolate to methyltetrahydrofolate, which is the main circulating form of folate and also forms precursors for purines and pyrimidines for DNA synthesis (Singh and Jaiswal, 2013). Methionine is a methyl donor and the methyl group is produced from methyltetrahydrofolate. This reaction is regulated by 2 enzymes: MS, which catalyzes the transfer of a methyl group from methyltetrahydrofolate to homocysteine and concurrently generates methionine and THF, and MTRR, which restores MS activity and is thus a critical determinant of homocysteine levels (Gaughan et al., 2001).

Several single-nucleotide polymorphisms (SNPs) of folate metabolism-related genes have been identified, including MTHFR C677T (rs1801133) (Frosst et al., 1995), MTHFR A1298C (rs1801131) (van der Put et al., 1998), MS A2756G (rs1805087) (Chen et al., 1998; Ma et al., 1999), and MTRR A66G (rs1801394) (Olteanu et al., 2002). These SNPs can modulate homocysteine levels, which may affect DNA synthesis and methylation by restricting the activity of folate metabolism-related enzymes.

Lee et al. (2006) analyzed a large number of subjects and found the first genetic evidence that the MTHFR C677T, MS A2756G, and MTRR A66G genotypes were independently associated with male infertility. In addition, SNP of the 3 enzymes may have a different impact on the folate cycle during spermatogenesis in the Korean population. 


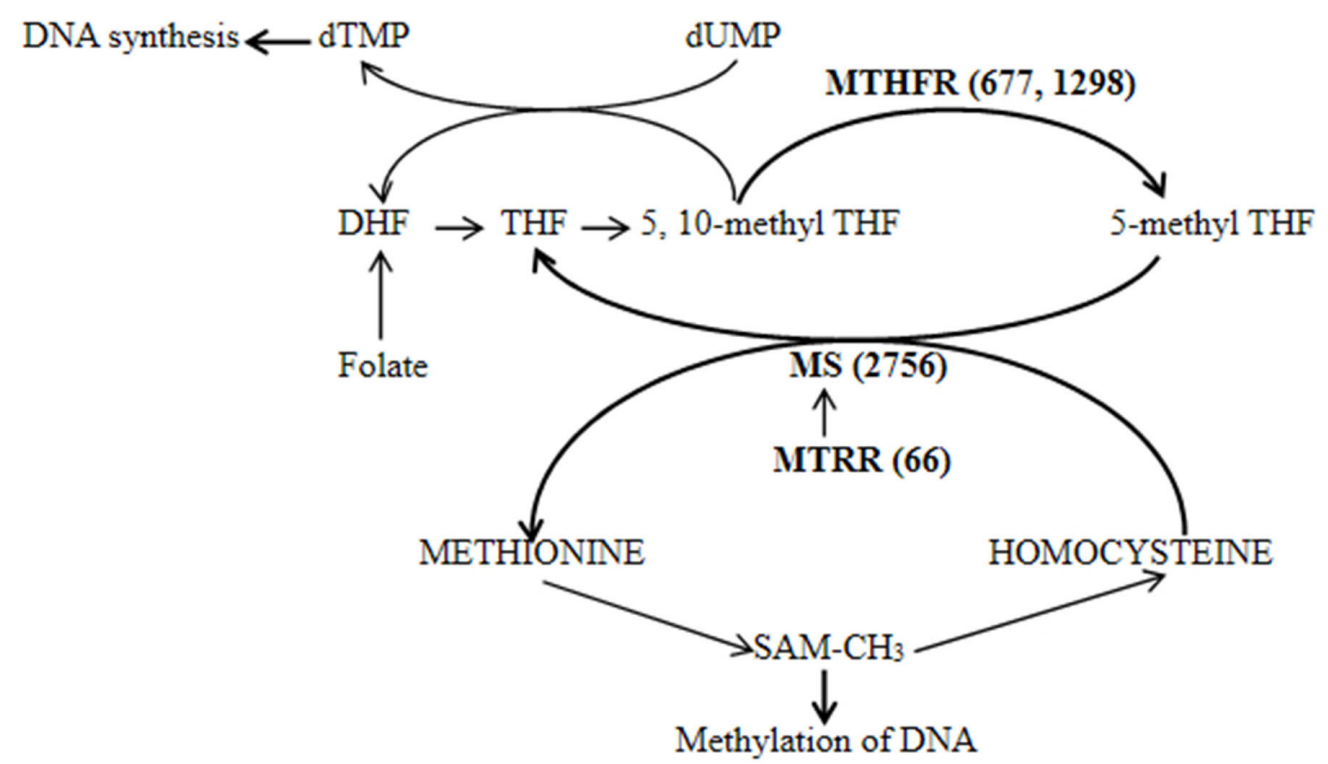

Figure 1. Overview of the human folic acid metabolic pathway and the role of methionine synthase reductase (MTRR), methylenetetrahydrofolate reductase (MTHFR), and methionine synthase (MS).

In this study, we examined the association between 4 SNPs (MTHFR C677T, MTHFR A1298C, MS A2756G, and MTRR A66G) and non-obstructive male infertility in China.

\section{MATERIAL AND METHODS}

\section{Patients and controls}

The study was approved by the Ethical Committee of Sichuan University. A total of 162 infertile men with non-obstructive azoospermia $(\mathrm{N}=100)$ or oligoasthenozoospermia (OA group; $\mathrm{N}=62$, sperm count $<20 \times 10^{6} / \mathrm{mL}$; progressive sperm motility $<50 \%$ ), and 120 men with proven fertility (at least 1 child) without assisted reproductive technologies were recruited for the study from July 2010 to June 2012. Semen analysis for sperm concentration, motility, and morphology was performed following the World Health Organization criteria (WHO, 1999). In addition, all patients underwent at least 2 semen analyses, and patients were verified to be free from chromosomal abnormalities, Y chromosome micro/macro-deletion, hypo-gonadotropic hypogonadism, infections, and obstructive azoospermia. Chromosomal abnormalities and $\mathrm{Y}$ chromosome micro/macro-deletion in the controls were also ruled out. The comprehensive clinical history of all patients was recorded, and other possible causes of male infertility such as clinical history of congenital bilateral absence of the vas deferens and varicocele endocrine were excluded. Written informed consent was obtained from all subjects.

\section{Mutation analysis}

Genomic DNA was extracted from whole blood using H.Q.\&.Q.Blood DNA Kit 
(AnHui U-gene Biotechnology Co., Ltd., Hefei, China) according to manufacturer instructions. Spectroscopic methods were performed to quantify the extracted genomic DNA and the DNA samples were stored at $-20^{\circ} \mathrm{C}$. A polymerase chain reaction protocol was used to genotype all SNPs. Primers were designed using PRIMER3 (http://www.bioinformatics.nl/cgi-bin/ primer3plus/primer3plus.cgi). Amplifications were performed in a total volume of $25 \mathrm{~mL}$ buffered solution containing approximately $200 \mathrm{ng}$ genomic DNA, $0.25 \mathrm{mM}$ dNTPs (TransGen, Beijing, China), $1.5 \mathrm{mM} \mathrm{Mg} \mathrm{Mg}^{2+}$ (Fermentas, Vilnius, Lithuania), $0.2 \mathrm{mM}$ of each primer (Invitrogen, Carlsbad, CA, USA), and 2.5 U Taq polymerase (Fermentas). Thermocycling consisted of $95^{\circ} \mathrm{C}$ for $2 \mathrm{~min} ; 35$ cycles of $95^{\circ} \mathrm{C}$ for $1 \mathrm{~min}$, annealing temperature (Table 1) for $30 \mathrm{~s}$, and $72^{\circ} \mathrm{C}$ for $30 \mathrm{~s}$; and a final 7 -min extension at $72^{\circ} \mathrm{C}$. After the reaction, samples were stored at $4^{\circ} \mathrm{C}$. Products were sequenced using an ABI 3730xl DNA Analyzer (Applied Biosystems, Foster City, CA, USA).

\section{Statistical analysis}

The allele and genotype frequencies of the patients and controls were calculated by counting. The chi-squared or Fisher exact test (2-sided) was performed to compare differences in mutation rates. The statistical package was used to estimate the odds ratio and $95 \%$ confidence intervals were the SPSS15.0 statistical software (SPSS Inc., Chicago, IL, USA). P values $<0.05$ were considered to be statistically significant.

\section{RESULTS}

We analyzed the 4 polymorphisms in the MTRR, MS, and MTHFR genes in infertile and fertile men by direct DNA sequencing. Table 1 and Figure 2 show the results of the MTHFR C677T, MTHFR A1298C, MS A2765G, and MTRR A66G analyses performed using direct DNA sequencing.

Table 1. List of SNPs analyzed along with PCR primers used for genotyping.

\begin{tabular}{lclcc}
\hline SNP & Chromosome & Forward primer/Reverse primer $\left(5^{\prime}-3^{\prime}\right)$ & Annealing temperature $\left({ }^{\circ} \mathrm{C}\right)$ & Fragment size $(\mathrm{bp})$ \\
\hline A66G & 5 & $\begin{array}{l}\text { GATTCAAGCCCAAGTAGT } \\
\text { TGCAGAAAATCCATGTAC }\end{array}$ & 53 & 383 \\
C677T & 1 & $\begin{array}{l}\text { CAGGACAGTGTGGGAGTTT } \\
\text { GCTGCGTGATGATGAAATC }\end{array}$ & 54 & 371 \\
A1298C & 1 & $\begin{array}{l}\text { CAGACCTTCCTTGCAAATA } \\
\text { ACTCCAGCATCACTCACTT } \\
\text { A2756G }\end{array}$ & 1 & $\begin{array}{l}\text { TGTTATCAGCATTGACCATTACTAC } \\
\text { CAGAAATTCTCTAAAATGATCCAAA }\end{array}$ \\
\hline
\end{tabular}

The results of statistical analysis of 4 polymorphisms in the fertile and non-obstructive infertile men are summarized in Table 2. All polymorphisms were in Hardy-Weinberg equilibrium ( $\mathrm{P}=0.922,0.797,0.512$, and 0.333 , respectively). Allelic frequencies for fertile men with the 66GG and 677TT variations in this study were similar to those in healthy Chinese men (Yang et al., 2013). The MTRR A66G, MTHFR C677T, MTHFR A1298C, and MS A2756G polymorphism data, according to our case-control analysis, showed no significant differences for individuals with infertility $(\mathrm{P}>0.05)$. 

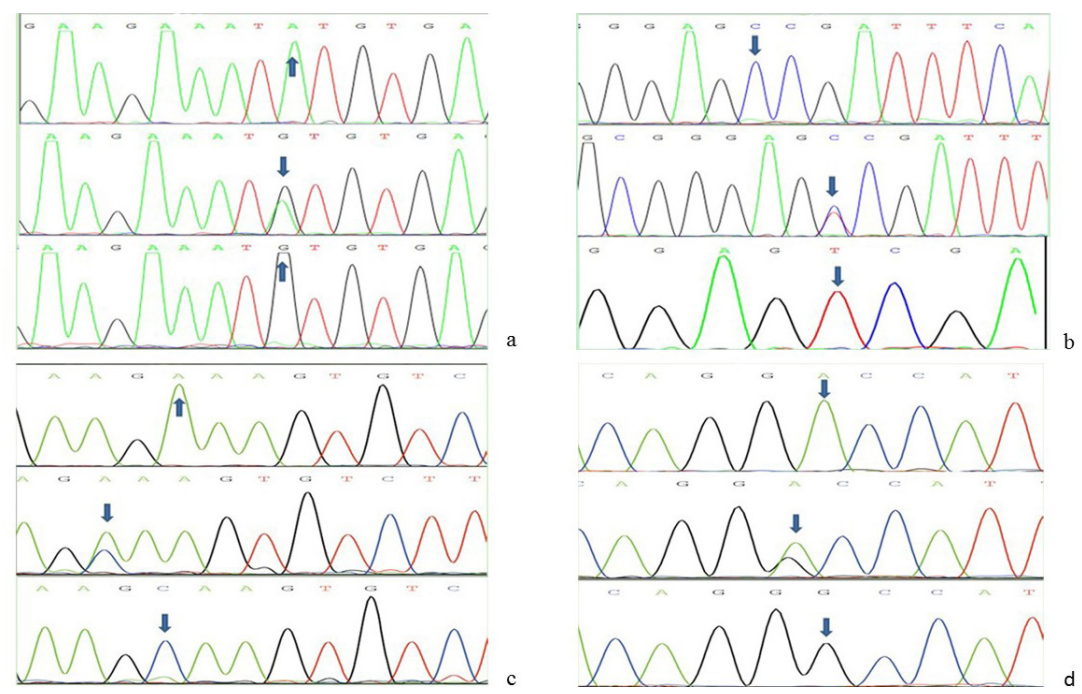

Figure 2. Sequence results of the MTRR, MTHFR, and MS genes. a. MTRR 66 (AA, AG, GG); b. MTHFR 677 (CC, CT, TT); c. MTHFR 1298 (AA, AC, CC); d. MS 2756 (AA, AG, GG).

Table 2. Distribution of the MTRR A66G, MTHFR C677T, MTHFR A1298C, and MS A2756G genotypes in infertile and fertile men.

\begin{tabular}{|c|c|c|c|c|}
\hline & Fertile men $(\mathrm{N}=120)$ & Infertile men $(\mathrm{N}=162)$ & OR $(95 \% \mathrm{CI})$ & $\mathrm{P}$ \\
\hline \multicolumn{5}{|l|}{ MTRR66 } \\
\hline $66 \mathrm{AA}$ & $(58.33 \%) 70$ & $(51.23 \%) 83$ & & \\
\hline $66 \mathrm{AG}$ & $(36.67 \%) 44$ & $(40.12 \%) 65$ & $1.246(0.758-2.049)$ & 0.386 \\
\hline $66 \mathrm{GG}$ & $(5.00 \%) 6$ & $(8.64 \%) 14$ & $1.968(0.718-5.391)$ & 0.182 \\
\hline $\mathrm{AG}+\mathrm{GG}$ & $(41.67 \%) 50$ & $(48.76 \%) 79$ & $1.333(0.828-2.145)$ & 0.237 \\
\hline A & $(76.67 \%) 184$ & $(71.30 \%) 231$ & & \\
\hline G & (23.33\%) 56 & $(28.70 \%) 93$ & $1.323(0.901-1.942)$ & 0.153 \\
\hline \multicolumn{5}{|l|}{ MTHFR677 } \\
\hline $677 \mathrm{CC}$ & $(40.00 \%) 48$ & $(37.65 \%) 61$ & & \\
\hline $677 \mathrm{CT}$ & $(45.00 \%) 54$ & $(47.53 \%) 77$ & $1.122(0.671-1.876)$ & 0.660 \\
\hline $677 \mathrm{TT}$ & $(15.00 \%) 18$ & $(14.81 \%) 24$ & $1.049(0.511-2.153)$ & 0.896 \\
\hline $\mathrm{CT}+\mathrm{TT}$ & $(60.00 \%) 72$ & $(62.34 \%) 101$ & $1.104(0.680-1.791)$ & 0.689 \\
\hline $\mathrm{C}$ & $(62.50 \%) 150$ & $(61.42 \%) 199$ & & \\
\hline $\mathrm{T}$ & $(37.50 \%) 90$ & $(38.58 \%) 125$ & $1.047(0.742-1.477)$ & 0.794 \\
\hline \multicolumn{5}{|c|}{ MTHFR 1298} \\
\hline $1298 \mathrm{AA}$ & $(66.67 \%) 80$ & $(62.35 \%) 101$ & & \\
\hline $1298 \mathrm{AC}$ & $(31.67 \%) 38$ & $(33.33 \%) 54$ & $1.126(0.677-1.871)$ & 0.648 \\
\hline $1298 \mathrm{CC}$ & $(1.67 \%) 2$ & $(4.32 \%) 7$ & $2.772(0.560-13.712)$ & 0.304 \\
\hline $\mathrm{AC}+\mathrm{CC}$ & $(33.33 \%) 40$ & $(37.65 \%) 61$ & $1.208(0.736-1.982)$ & 0.454 \\
\hline A & $(82.50 \%) 198$ & $(79.01 \%) 256$ & & \\
\hline $\mathrm{C}$ & $(17.50 \%) 42$ & $(20.99 \%) 68$ & $1.252(0.817-1.919)$ & 0.301 \\
\hline \multicolumn{5}{|l|}{$M S 2756$} \\
\hline 2756AA & $(84.17 \%) 101$ & $(76.54 \%) 124$ & & \\
\hline $2756 \mathrm{AG}$ & $(14.17 \%) 17$ & $(21.60 \%) 35$ & $1.677(0.888-3.168)$ & 0.109 \\
\hline $2756 \mathrm{GG}$ & $(1.67 \%) 2$ & $(1.85 \%) 3$ & $1.222(0.200-7.453)$ & 1.000 \\
\hline $\mathrm{AG}+\mathrm{GG}$ & $(15.84 \%) 19$ & $(23.45 \%) 38$ & $1.629(0.885-2.999)$ & 0.115 \\
\hline A & $(91.25 \%) 219$ & $(87.35 \%) 283$ & & \\
\hline $\mathrm{G}$ & $(8.75 \%) 21$ & $(12.65 \%) 41$ & $1.511(0.868-2.631)$ & 0.143 \\
\hline
\end{tabular}

Variations in the polymorphisms analyzed in the azoospermia group are summarized in Table 3. Differences in MTRR A66G, MTHFR C677T, MTHFR A1298C, and MS A2756G 
were not statistically significant.

\begin{tabular}{|c|c|c|c|c|c|}
\hline Gene & Azoospermia & & & ele type & \\
\hline \multirow{2}{*}{ MTRR66 } & & $66 \mathrm{AA}$ & $66 \mathrm{AG}$ & $66 \mathrm{GG}$ & $\mathrm{AG}+\mathrm{GG}$ \\
\hline & $\begin{array}{l}\text { Frequency }(\%)(\mathrm{N}=100) \\
\text { OR }(95 \% \mathrm{CI}) \\
\mathrm{P} \\
\text { Fertile men }(\%)(\mathrm{N}=120)\end{array}$ & $\begin{array}{l}(59.00) 59 \\
(58.33) 70\end{array}$ & $\begin{array}{c}(31.00) 31 \\
0.836(0.470-1.486) \\
0.541 \\
(36.67) 44\end{array}$ & $\begin{array}{c}(10.00) 10 \\
1.977(0.678-5.763) \\
0.205 \\
(5.00) 6\end{array}$ & $\begin{array}{c}(41.00) 41 \\
0.973(0.568-1.668) \\
0.920 \\
(41.67) 50\end{array}$ \\
\hline \multirow[t]{2}{*}{ MTHFR677 } & & $677 \mathrm{CC}$ & $677 \mathrm{CT}$ & $677 \mathrm{TT}$ & $\mathrm{CT}+\mathrm{TT}$ \\
\hline & $\begin{array}{l}\text { Frequency }(\%)(\mathrm{N}=100) \\
\text { OR }(95 \% \mathrm{CI}) \\
\mathrm{P} \\
\text { Fertile men }(\%)(\mathrm{N}=120)\end{array}$ & $\begin{array}{l}(36.00) 36 \\
(40.00 \%) 48\end{array}$ & $\begin{array}{c}(49.00) 49 \\
1.210(0.677-2.161) \\
0.519 \\
(45.00 \%) 54\end{array}$ & $\begin{array}{c}(15.00) 15 \\
1.111(0.494-2.498) \\
0.799 \\
(15.00 \%) 18\end{array}$ & $\begin{array}{c}(64.00) 64 \\
1.185(0.685-2.050) \\
0.543 \\
(60.00 \%) 72\end{array}$ \\
\hline \multirow[t]{2}{*}{ MTHFR 1298} & & $1298 \mathrm{AA}$ & $1298 \mathrm{AC}$ & $1298 \mathrm{CC}$ & $\mathrm{AC}+\mathrm{CC}$ \\
\hline & $\begin{array}{l}\text { Frequency }(\%)(\mathrm{N}=100) \\
\text { OR }(95 \% \mathrm{CI}) \\
\mathrm{P} \\
\text { Fertile men }(\%)(\mathrm{N}=120)\end{array}$ & $\begin{array}{l}(66.00) 66 \\
(66.67 \%) 80\end{array}$ & $\begin{array}{c}(31.00) 31 \\
0.989(0.556-1.758) \\
0.970 \\
(31.67 \%) 38\end{array}$ & $\begin{array}{c}(3.00) 3 \\
1.818(0.295-11.206) \\
0.660 \\
(1.67 \%) 2\end{array}$ & $\begin{array}{c}(34.00) 34 \\
1.030(0.588-1.806) \\
0.917 \\
(33.33 \%) 40\end{array}$ \\
\hline \multirow[t]{2}{*}{ MS2756 } & & $2756 \mathrm{AA}$ & $2756 \mathrm{AG}$ & $2756 \mathrm{GG}$ & $\mathrm{AG}+\mathrm{GG}$ \\
\hline & $\begin{array}{l}\text { Frequency }(\%)(\mathrm{N}=100) \\
\text { OR }(95 \% \mathrm{CI}) \\
\mathrm{P} \\
\text { Fertile men }(\%)(\mathrm{N}=120)\end{array}$ & $\begin{array}{l}(74.00) 74 \\
(84.17 \%) 101\end{array}$ & $\begin{array}{c}(24.00) 24 \\
1.927(0.967-3.841) \\
0.060 \\
(14.17 \%) 17\end{array}$ & $\begin{array}{c}(2.00) 2 \\
1.365(0.188-9.913) \\
1.000 \\
(1.67 \%) 2\end{array}$ & $\begin{array}{c}(26.00) 26 \\
1.868(0.962-3.625) \\
0.067 \\
(15.84 \%) 19\end{array}$ \\
\hline
\end{tabular}

The allelic frequencies of the 4 SNPs in the OA group are listed in Table 4. Three SNPs (MTHFR C677T, MTHFRA1298C, and MS A2756G) were not associated with the OA group, but MTRR A66G was significantly associated with the OA group. The frequencies of MTRR A66G genotypes $\mathrm{AG}$ and $\mathrm{AG}+\mathrm{GG}$ were associated with the OA group $(\mathrm{P}=0.013,0.012)$.

\begin{tabular}{|c|c|c|c|c|c|}
\hline \multirow{2}{*}{$\begin{array}{l}\text { Gene } \\
\text { MTRR66 }\end{array}$} & \multirow[t]{2}{*}{$\mathrm{OA}$} & \multicolumn{4}{|c|}{ Allele type } \\
\hline & & $66 \mathrm{AA}$ & $66 \mathrm{AG}$ & $66 \mathrm{GG}$ & $\mathrm{AG}+\mathrm{GG}$ \\
\hline & $\begin{array}{l}\text { Frequency }(\%)(\mathrm{N}=62) \\
\text { OR }(95 \% \mathrm{CI}) \\
\mathrm{P} \\
\text { Fertile men }(\%)(\mathrm{N}=120)\end{array}$ & $\begin{array}{l}(38.71) 24 \\
(58.33) 70\end{array}$ & $\begin{array}{c}(54.84) 34 \\
2.254(1.183-4.293) \\
0.013^{\mathrm{a}} \\
(36.67) 44\end{array}$ & $\begin{array}{c}(6.45) 4 \\
1.944(0.505-7.481) \\
0.453 \\
(5.00) 6\end{array}$ & $\begin{array}{c}(61.29) 38 \\
2.217(1.184-4.149) \\
0.012^{\mathrm{a}} \\
(41.67) 50\end{array}$ \\
\hline \multirow[t]{2}{*}{ MTHFR677 } & & $677 \mathrm{CC}$ & $677 \mathrm{CT}$ & $677 \mathrm{TT}$ & $\mathrm{CT}+\mathrm{TT}$ \\
\hline & $\begin{array}{l}\text { Frequency }(\%)(\mathrm{N}=62) \\
\text { OR }(95 \% \mathrm{CI}) \\
\mathrm{P} \\
\text { Fertile men }(\%)(\mathrm{N}=120)\end{array}$ & $\begin{array}{l}(40.32) 25 \\
(40.00 \%) 48\end{array}$ & $\begin{array}{c}(45.16) 28 \\
0.996(0.512-1.936) \\
0.990 \\
(45.00 \%) 54\end{array}$ & $\begin{array}{c}(14.52) 9 \\
0.960(0.377-2.445) \\
0.932 \\
(15.00 \%) 18\end{array}$ & $\begin{array}{c}(59.68) 37 \\
0.987(0.528-1.844) \\
0.966 \\
(60.00 \%) 72\end{array}$ \\
\hline \multirow[t]{2}{*}{ MTHFR 1298} & & 1298AA & $1298 \mathrm{AC}$ & $1298 \mathrm{CC}$ & $\mathrm{AC}+\mathrm{CC}$ \\
\hline & $\begin{array}{l}\text { Frequency }(\%)(\mathrm{N}=62) \\
\text { OR }(95 \% \mathrm{CI}) \\
\mathrm{P} \\
\text { Fertile men }(\%)(\mathrm{N}=120)\end{array}$ & $\begin{array}{l}(56.45) 35 \\
(66.67 \%) 80\end{array}$ & $\begin{array}{c}(37.10) 23 \\
1.383(0.720-2.657) \\
0.329 \\
(31.67 \%) 38\end{array}$ & $\begin{array}{c}(6.45) 4 \\
4.571(0.800-26.129) \\
0.084 \\
(1.67 \%) 2\end{array}$ & $\begin{array}{c}(43.55) 27 \\
1.543(0.822-2.895) \\
0.176 \\
(33.33 \%) 40\end{array}$ \\
\hline \multirow[t]{2}{*}{$M S 2756$} & & $2756 \mathrm{AA}$ & $2756 \mathrm{AG}$ & $2756 \mathrm{GG}$ & $\mathrm{AG}+\mathrm{GG}$ \\
\hline & $\begin{array}{l}\text { Frequency }(\%)(\mathrm{N}=62) \\
\text { OR }(95 \% \mathrm{CI}) \\
\mathrm{P} \\
\text { Fertile men }(\%)(\mathrm{N}=120)\end{array}$ & $(84.17 \%) 101$ & $\begin{array}{c}(17.74) 11 \\
1.307(0.570-3.000) \\
0.527 \\
(14.17 \%) 17\end{array}$ & $\begin{array}{c}(1.61) 1 \\
1.010(0.089-11.407) \\
1.000 \\
(1.67 \%) 2\end{array}$ & $\begin{array}{c}(19.35) 12 \\
1.276(0.574-2.834) \\
0.549 \\
(15.84 \%) 19\end{array}$ \\
\hline
\end{tabular}

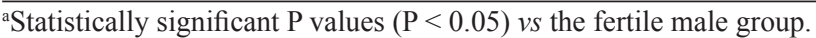


We analyzed the gene-to-gene correlation between 3 genes (MTRR A66G, MTHFR $\mathrm{C} 677 \mathrm{~T}$, and $M S \mathrm{~A} 2756 \mathrm{G}$ ) in the OA groups (Table 5). The genotypes MTHFR C677T and $M S$ A2756G were not associated with the MTRR A66G genotype. However, the MTHFR 677TT genotype was generally increased for MTRR 66AA genotypes $(\mathrm{P}=0.078)$.

\begin{tabular}{|c|c|c|c|c|c|c|c|c|c|c|c|c|c|}
\hline \multirow{3}{*}{$\begin{array}{ll}\begin{array}{l}\text { Patient } \\
\text { group }\end{array} & \text { SNP } \\
\text { OA group } & 66\end{array}$} & & \multicolumn{12}{|c|}{ Allele type } \\
\hline & & \multicolumn{4}{|c|}{$\mathrm{AA}$} & \multicolumn{4}{|c|}{$\mathrm{AG}$} & \multicolumn{4}{|c|}{ GG } \\
\hline & & $\mathrm{C} \%{ }^{\mathrm{b}}(\mathrm{N})$ & $\mathrm{P} \%{ }^{\mathrm{c}}(\mathrm{N})$ & $\mathrm{P}$ & OR & $\mathrm{C} \%(\mathrm{~N})$ & $\mathrm{P} \%(\mathrm{~N})$ & $\mathrm{P}$ & OR & $\mathrm{C} \%(\mathrm{~N})$ & $\mathrm{P} \%(\mathrm{~N})$ & $P$ & OR \\
\hline \multirow[t]{4}{*}{677} & $\mathrm{CC}$ & $53.3(16)$ & $41.7(10)$ & & & $22.2(4)$ & $44.1(15)$ & & & $(50.00) 1$ & $0.0(0)$ & & \\
\hline & CT & $46.6(14)$ & $45.8(11)$ & 0.779 & $1.26(0.4-3.8)$ & $55.6(10)$ & $44.1(15)$ & 0.211 & $0.40(0.1-1.5)$ & (50.00) 1 & $50.0(2)$ & 1 & $\begin{array}{c}3.0 \\
(0.7-14.9)\end{array}$ \\
\hline & TT & $0.0(0)$ & $12.5(3)$ & $0.078^{\mathrm{a}}$ & & $22.2(4)$ & $11.8(4)$ & 0.183 & $0.27(0.0-1.6)$ & (0.00) 0 & $50.0(2)$ & 0.333 & \\
\hline & $\mathrm{CT}+\mathrm{TT}$ & 46.7 (14) & $58.3(14)$ & 0.425 & $1.60(0.5-4.7)$ & 77.8 (14) & 55.9 (19) & 0.142 & $0.36(0.1-1.3)$ & (50.00) 1 & $100.0(4)$ & 0.333 & \\
\hline \multirow{4}{*}{2756} & AA & $80.0(24)$ & $87.5(21)$ & & & $83.3(15)$ & $73.5(25)$ & & & (50.00) 1 & $100.0(4)$ & & \\
\hline & $\mathrm{AG}$ & $20.0(6)$ & $12.5(3)$ & 0.715 & $0.57(0.1-2.6)$ & $11.1(2)$ & $23.5(8)$ & 0.461 & $2.40(0.4-12.8)$ & (50.00) 1 & $0.0(0)$ & 0.333 & \\
\hline & GG & $0.0(0)$ & $0.0(0)$ & & & $5.6(1)$ & $2.9(1)$ & 1 & $0.60(0.0-10.3)$ & $(0.00) 0$ & $0.0(0)$ & & \\
\hline & $\mathrm{AG}+\mathrm{GG}$ & $20.0(6)$ & $12.5(3)$ & 0.715 & $0.57(0.1-2.6)$ & $16.7(3)$ & $26.5(9)$ & 0.507 & $1.80(0.4-7.7)$ & (50.00) 1 & $0.0(0)$ & 0.333 & \\
\hline
\end{tabular}

${ }^{a}$ Not significant $(P>0.05)$ but showed a tendency toward significance. ${ }^{b}$ Percentage of fertile men. ${ }^{\text {Percentage of }}$ infertile men.

\section{DISCUSSION}

Folate level may affect spermatogenesis by inducing DNA hypomethylation. This can disrupt gene expression and lead to uracil misincorporation during DNA synthesis, causing errors in DNA repair, strand breakage, and chromosomal anomalies. Mice lacking the MTHFR gene showed delayed maturation of the external genitalia and spermatogenic failure, which may explain some degree of human male infertility (Kelly et al., 2005). In humans, an improvement in spermatozoa number and motility as well as a decrease in round cell number were observed after 1 cycle of spermatogenesis with folinic acid treatment (Bentivoglio et al., 1993). These data indicate that folate metabolism plays an important role in maintaining spermatogenesis.

In our study, we analyzed the association between the 4 SNPs of 3 genes and the folate cycle in infertile men. We selected patients by performing karyotyping and azoospermia factor microdeletion detection, and classified patients without any chromosomal abnormalities and azoospermia factor microdeletion into 2 groups (azoospermia and OA).

Previous studies (Bezold et al., 2001; Ebisch et al., 2003; Stuppia et al., 2003; Park et al., 2005; Singh et al., 2005; A et al., 2007; Tetik et al., 2008; Ravel et al., 2009; Gava et al., 2011a,b; Safarinejad et al., 2011) evaluated the association between the MTHFR C677T polymorphism and infertility in patients from Europe, Asia, and Brazil. Bezold et al. (2001), Singh et al. (2005), and Park et al. (2005) showed that the frequency of the TT homozygote and CT heterozygote in MTHFR C677T was significant in infertile patients. Singh et al. (2005) also found that there were no T homozygotes in the control population, which showed that the $\mathrm{T}$ allele occurs at a very low frequency in the control population. However, Ebish et al. (2003), Stuppia et al. (2003), and Ravel et al. (2009) found no statistical significance of the C677T variation in infertile males and indicated the importance of folate in spermatogenesis. Our 
results agree with those of previous studies. Some previous studies (Park et al., 2005; Lee et al., 2006; Ravel et al., 2009; Singh et al., 2010; Gava et al., 2011a,b; Safarinejad et al., 2011; Gupta et al., 2013) examined the influence of the MTHFR A1298C polymorphisms in infertile patients. Singh et al. (2010) reported that MTHFR A1298C may be an additional genetic risk factor for primary male infertility in the Indian population. However, Park et al. (2005), Lee et al. (2006), Ravel et al. (2009), Safarinejad et al. (2011), and Gupta et al. (2013) found no statistical significance for the A1298C variation in unexplained infertile males. Most studies suggested that some gene(s) other than MTHFR in the DNA methylation pathway affected male infertility.

Little is known regarding the role of MTRR A66G and MS A2756G in male infertility. Lee et al. (2006) reported that the frequencies of MTRR 66GG genotypes in non-obstructive infertile men, MS 2756GG genotypes in the azoospermia group, and MTRR 66GG in the OA group were higher compared with those in fertile Korean men. Gava et al. (2011b) showed that MS A2756G polymorphisms may be important in the predisposition to primary infertility in Brazilian men. However, Farcas et al. (2009) and Ravel et al. (2009) suggested that these polymorphisms in infertile men were not significantly more common than in controls.

Interesting, Singh et al. (2010) and Gupta et al. (2013) found very different results in the same region of MTHFR A1298C. Contrasting outcomes also have been shown in Brazilian men in 2 studies in the same ethnic background (Gava et al., 2011a,b). Our study and that of A et al. (2007) also found contrasting outcomes for MTHFR C677T. Ethnic and geographic variation may explain these results. MTHFR C677T was less frequent among Africans than among Caucasians (Rozen, 1997; Stevenson et al., 1997). The frequency of MTHFR A1298C also differed across populations (Botto and Yang, 2000). Moreover, gene-nutrient and geneenvironmental factors have been shown to affect the impact of these MTHFR genetic variants (Toffoli and De Mattia, 2008). Ravel et al. (2009) have suggested that the different outcomes are due to population stratification rather than a causal link with the phenotype. Different methods with different sensitivities and accuracies may contribute to the contrasting outcomes.

Our results revealed an association between the MTHFR and MTRR genotypes and OA group. Although A66G and other SNPs were not associated with the OA group, the MTHFR 677TT genotype showed a trend toward increased MTRR 66AA types $(\mathrm{P}=0.078)$. Additional studies including a larger number of subjects are necessary. In conclusion, the SNP MTRR A66G may be a genetic risk factor for infertility for Chinese men, particularly in the OA patient group. The exact mechanism underlying the folate pathway remains unclear, but mechanisms have been suggested to explain the cause of infertility. Lee et al. (2006) concluded that these SNPs were independently associated with male infertility. The SNP of each enzyme may affect enzyme activity to varying degrees by influencing the three-dimensional structure and amino acid substitution. Previous studies showed that the MTRR 66GG genotype contributed more than the MTHFR 677TT and MS 2756GG genotypes to the regulation of homocysteine levels (Gaughan et al., 2001; Jacques et al., 2003; Zijno et al., 2003). Our findings are partly consistent with these results. Future studies including subjects of different ethnic and geographic origins should be conducted for other genes encoding crucial enzymes in the folate metabolic pathway.

\section{ACKNOWLEDGMENTS}

Research supported by the Bio-resource Research and Utilization Joint Key Laboratory of Sichuan-Chongqing, Institute of Medical Genetics, College of Life Science, Sichuan 
University. We are grateful to the patients and volunteers who participated in this study.

\section{REFERENCES}

A ZC, Yang Y, Zhang SZ, Li N, et al. (2007). Single nucleotide polymorphism C677T in the methylenetetrahydrofolate reductase gene might be a genetic risk factor for infertility for Chinese men with azoospermia or severe oligozoospermia. Asian J. Androl. 9: 57-62.

Ammar T, Sidhu PS and Wilkins CJ (2012). Male infertility: the role of imaging in diagnosis and management. $B r . J$. Radiol. 85: 59-68.

Augarten A, Yahav Y, Kerem BS, Hallen D, et al. (1994). Congenital bilateral absence of vas deferens in the absence of cystic fibrosis. Lancet 344: 1473-1474.

Bentivoglio G, Melica F and Cristoforoni P (1993). Folinic acid in the treatment of human male infertility. Fertil. Steril. 60: 698-701.

Bezold G, Lange M and Peter RU (2001). Homozygous methylenetetrahydrofolate reductase C677T mutation and male infertility. N. Engl. J. Med. 344: 1172-1173.

Botto LD and Yang Q (2000). 5, 10-Methylenetetrahydrofolate reductase gene variants and congenital anomalies: a HuGE review. Am. J. Epidemiol. 151: 862-877.

Chen J, Giovannucci E, Hankinson SE, Ma J, et al. (1998). A prospective study of methylenetetrahydrofolate reductase and methionine synthase gene polymorphisms, and risk of colorectal adenoma. Carcinogenesis 19: 2129-2132.

Ebisch IM, van Heerde WL, Thomas CM, van der Put N, et al. (2003). C677T methylenetetrahydrofolate reductase polymorphism interferes with the effects of folic acid and zinc sulfate on sperm concentration. Fertil. Steril. 80: 1190-1194.

Fang JY and Xiao SD (2003). Folic acid, polymorphism of methyl-group metabolism genes, and DNA methylation in relation to GI carcinogenesis. J. Gastroenterol. 38: 821-829.

Farcas MF, Trifa AP, Militaru M, Csernik FA, et al. (2009). Association of methionine synthase A2756G SNP, methionine synthase reductase A66G and male infertility. Rev. Romana Med. Lab. 17: 17-24.

Frosst P, Blom H, Milos R, Goyette P, et al. (1995). A candidate genetic risk factor for vascular disease: a common mutation in methylenetetrahydrofolate reductase. Nat. Genet. 10: 111.

Gaughan DJ, Kluijtmans LA, Barbaux S, McMaster D, et al. (2001). The methionine synthase reductase (MTRR) A66G polymorphism is a novel genetic determinant of plasma homocysteine concentrations. Atherosclerosis 157: 451-456.

Gava MM, Chagas Ede O, Bianco B, Christofolini DM, et al. (2011a). Methylenetetrahydrofolate reductase polymorphisms are related to male infertility in Brazilian men. Genet. Test. Mol. Biomarkers 15: 153-157.

Gava MM, Kayaki EA, Bianco B, Teles JS, et al. (2011b). Polymorphisms in folate-related enzyme genes in idiopathic infertile Brazilian men. Reprod. Sci. 18: 1267-1272.

Gupta N, Sarkar S, David A, Gangwar PK, et al. (2013). Significant impact of the MTHFR polymorphisms and haplotypes on male infertility risk. PloS One 8: e69180.

Jacques PF, Bostom AG, Selhub J, Rich S, et al. (2003). Effects of polymorphisms of methionine synthase and methionine synthase reductase on total plasma homocysteine in the NHLBI Family Heart Study. Atherosclerosis 166: 49-55.

Kara E and Simoni M (2010). Genetic screening for infertility: When should it be done? Middle East Fertil. Soc. J. 15: 139-145.

Kelly TL, Neaga OR, Schwahn BC, Rozen R, et al. (2005). Infertility in 5,10-methylenetetrahydrofolate reductase (MTHFR)deficient male mice is partially alleviated by lifetime dietary betaine supplementation. Biol. Reprod. 72: 667-677.

Lee HC, Jeong YM, Lee SH, Cha KY, et al. (2006). Association study of four polymorphisms in three folate-related enzyme genes with non-obstructive male infertility. Hum. Reprod. 21: 3162-3170.

Lee JY, Dada R, Sabanegh E, Carpi A, et al. (2011). Role of genetics in azoospermia. Urology 77: 598-601.

Lee S, Lee S-H, Chung T-G, Kim H-J, et al. (2003). Molecular and cytogenetic characterization of two azoospermic patients with X-autosome translocation. J. Assist. Reprod. Genet. 20: 385-389.

Ma J, Stampfer MJ, Christensen B, Giovannucci E, et al. (1999). A polymorphism of the methionine synthase gene: association with plasma folate, vitamin B12, homocyst (e) ine, and colorectal cancer risk. Cancer Epidemiol. Biomarkers Prev. 8: 825-829.

Olteanu H, Munson T and Banerjee R (2002). Differences in the efficiency of reductive activation of methionine synthase and exogenous electron acceptors between the common polymorphic variants of human methionine synthase reductase. Biochemistry 41: 13378-13385.

Park JH, Lee HC, Jeong YM, Chung TG, et al. (2005). MTHFR C677T polymorphism associates with unexplained infertile male factors. J. Assist. Reprod. Genet. 22: 361-368. 
Ravel C, Chantot-Bastaraud S, Chalmey C, Barreiro L, et al. (2009). Lack of association between genetic polymorphisms in enzymes associated with folate metabolism and unexplained reduced sperm counts. PLoS One 4: e6540.

Rozen R (1997). Genetic predisposition to hyperhomocysteinemia: deficiency of methylenetetrahydrofolate reductase (MTHFR). Thromb. Haemost. 78: 523-526.

Safarinejad MR, Shafiei N and Safarinejad S (2011). Relationship between genetic polymorphisms of methylenetetrahydrofolate reductase (C677T, A1298C, and G1793A) as risk factors for idiopathic male infertility. Reprod. Sci. 18: 304-315.

Simoni M and Wieacker P (2010). Cytogenetic and molecular genetic investigations, Andrology. Springer, New York, 119-124.

Singh K and Jaiswal D (2013). One-carbon metabolism, spermatogenesis, and male infertility. Reprod. Sci. 20: 622-630.

Singh K, Singh SK and Raman R (2010). MTHFR A1298C polymorphism and idiopathic male infertility. J. Postgrad. Med. 56: 267-269.

Singh K, Singh SK, Sah R, Singh I, et al. (2005). Mutation C677T in the methylenetetrahydrofolate reductase gene is associated with male infertility in an Indian population. Int. J. Androl. 28: 115-119.

Stevenson RE, Schwartz CE, Du Y and Adams Jr MJ (1997). Differences in methylenetetrahydrofolate reductase genotype frequencies, between Whites and Blacks. Am. J. Hum. Genet. 60: 229.

Stuppia L, Gatta V, Scarciolla O, Colosimo A, et al. (2003). The methylenetethrahydrofolate reductase (MTHFR) C677T polymorphism and male infertility in Italy. J. Endocrinol. Invest. 26: 620-622.

Tetik A, Aliyeva U, Cetintas V, Semerci B, et al. (2008). Influence of methylenetetrahydrofolate reductase (MTHFR) C677T and A1298C gene polymorphisms on male infertility in Turkish infertile men with azoospermia and oligozoospermia. Eur. Urol. 7: 92.

Toffoli G and De Mattia E (2008). Pharmacogenetic relevance of MTHFR polymorphisms. Pharmacogenomics 9: 11951206.

van der Put NM, Gabreëls F, Stevens E, Smeitink JA, et al. (1998). A second common mutation in the methylenetetrahydrofolate reductase gene: an additional risk factor for neural-tube defects? Am. J. Hum. Genet. 62 : 1044-1051.

Yang B, Liu Y, Li Y, Fan S, et al. (2013). Geographical distribution of MTHFR C677T, A1298C and MTRR A66G gene polymorphisms in China: findings from 15357 adults of Han nationality. PLoS One 8: e57917.

Zijno A, Andreoli C, Leopardi P, Marcon F, et al. (2003). Folate status, metabolic genotype, and biomarkers of genotoxicity in healthy subjects. Carcinogenesis 24: 1097-1103. 